\title{
Cardiovascular Pathology Forecasting in Trained Workers Exposed Mercury
}

\author{
Irina V. Kudaeva \\ Clinic Department \\ FSBSI «East-Siberian Institute of Medical and Ecological \\ Researches» \\ Angarsk, Russia \\ kudaeva_irina@mail.ru
}

\section{Olga A. Dyakovich}

Department of Clinical and Experimental Researches FSBSI «East-Siberian Institute of Medical and Ecological Research»

Angarsk, Russia

dyakovich.olga@mail.ru

\begin{abstract}
There were examined 77 people trained workers exposed in the workplace of metallic mercury vapors from 4-5 year intervals, who were divided into groups according to the time at the time of examination: I group - 5-9 years, II group 10-15 years old, III group - 15 years or more. All individuals were studied levels of ceruloplasmin level and gamma glutamyltransferase in the blood serum, atherogenic index, cholesterol levels in low density lipoproteins (LDL). Forecasting was performed using multiple linear regression straight stepwise procedure of adding features.

Dynamic examination of trained workers in contact with the mercury, showed an increase of hypertension and coronary heart disease with increasing work experience. The incidence of hypertension and coronary heart disease increased by 1.5-2 times, exceeding the general population prevalence rates in these age groups. Analysis of biochemical parameters at the time of examination allows us to conclude that the atherogenic index increases with increasing exposure mercury load, cholesterol of low density lipoprotein does not go beyond the boundaries of acceptable values, but close to the upper border of the reference $(3.8 \mathrm{mmol} / \mathrm{l})$. Considering the significant increase in the predicted concentration of ceruloplasmin in 4-5 years, should expect an intensification of pro-atherogenic process, requiring preventive measures, aimed primarily at enhancing antioxidant protection.
\end{abstract}

Keywords - Forecasting, ceruloplasmin, mercury poisoning, hypertension, coronary heart disease.

\section{INTRODUCTION}

Forecasting changes in the concentration of biochemical parameters when exposed to harmful production factors is one of the promising areas of biomedical simulation. The results of these studies on the basis of current analyzes allow to predict its value changes after a certain period of time predict the development of diseases in development of which this modification plays a pathogenic role.

\author{
Elena V. Katamanova \\ Clinic Department \\ FSBSI «East-Siberian Institute of Medical and Ecological \\ Research» \\ Angarsk, Russia \\ krisla08@rambler.ru
}

Viktor S. Rukavishnikov

Department of Management

FSBSI «East-Siberian Institute of Medical and Ecological Research»

Angarsk, Russia

rvs_2010@mail.ru

Cardiovascular disease (CVD) associated with atherosclerosis is the leading cause of adult mortality as an economically developed and developing countries. It should be noted that a change of biochemical indicators that are part of major cardiovascular risk factors, causes, including prolonged contact with toxic substances such as mercury, which has a wide range of toxic effects on the human body. One of the non-specific manifestations of prolonged exposure to this toxicant, differing among workers with no signs of mercury intoxication is the atherosclerotic events and hypertension [1]. In particular, it was found that a high mercury content in the hair associated with increased progression of atherosclerosis and CVD risk [2]. Shown mercury role in the development of atherosclerosis and conditions in vitro [3]. The potential role of the toxicant as CVD risk sets in cohort studies of risk factors for coronary heart disease [4, 5], among dentists who have occupational exposure to mercury [6], as well as among workers exposed mercury [7]. One possible mechanism of action of mercury on the activation of pro-atherogenic process is oxidative stress. It is shown that persons exposed in a production environment with mercury throughout the exposure period, there was a statistically significant increase in the level of ceruloplasmin (CP) and the pro-atherogenic cholesterol fractions in the dynamics of examination $[8,9,10]$. At the same time, it sets the fact that the middle-aged men with dyslipidemia, have higher levels of serum ceruloplasmin (but not extending beyond the reference value), which in turn increases the risk of cardiovascular disease compared to a control group [11].

Thus, the presence information of ceruloplasmin concentration together with data on the state of lipid metabolism (total cholesterol and its fractions) with a projected increase in the level of ceruloplasmin and an actual increase in the content of cholesterol pro-atherogenic 
fractions indicates a high risk of developing atherosclerotic changes $[12,13,14]$. At the same time, the determination of ceruloplasmin does not apply to screening methods for the study, and therefore the holding of the predicted calculate its concentration allows, on the one hand to avoid additional on laboratory diagnosis costs and, on the other hand, to improve the diagnostic value of the results of the study in lipid metabolism and forecasting of the development of their violations.

The objective of this research is development a method that allows to forecast the concentration of ceruloplasmin in 4-5 years, working with its activities contact with mercury. The resulting indicator in conjunction with lipid metabolism can be used by public health agencies and research institutions for risk prediction of cardiovascular diseases in surveyed workers and will develop a program of preventive measures.

\section{MATERIALS AND METHODS}

There were examined 77 people trained workers exposed in the workplace of metallic mercury vapors from 4-5 year intervals, who were divided into groups according to the time at the time of examination: I group - 5-9 years, II group - 10-15 years old, III group - 15 years or more. The criterion for exclusion from the survey group is exceeding the reference value of the level of gamma-glutamyl transferase by 3 times (up to $200 \mathrm{U} / \mathrm{L}$ ). The diagnosis of cardiovascular disease (arterial hypertension and ischemic heart disease) formulated on the basis of the International Classification of Diseases (ICD X).

All individuals were studied levels of ceruloplasmin level and gamma glutamyltransferase in the blood serum at the time of research. Determination of ceruloplasmin was conducted at the biochemical photometer («Cormay multy», Poland) by method based on the specific interaction between the ceruloplasmin polyclonal antibody and appropriate antigen antiserum at the optimum $\mathrm{pH}(7.5)$ in the presence of polyethylene glycol ( «Sentinel», Italy). Gamma-glutamyl transferase was determined by the kinetic colorimetric method for Persijin \& van der Slik, standardized with respect to the method recommended by the IFCC using a test kit ( «Human», Germany) at the biochemical photometer («Cormay multy», Poland). It is found that statistically significant differences in cohort studies of persons exposed mercury observed at the interval between inspections for at least 4-5 years.

Total cholesterol was determined in fresh serum samples (10 .mu.l) colorimetric enzymatic method using CHOLESTEROL liquicolor test (HUMAN, Germany). Triglycerides were determined by enzymatic colorimetric test using a set of TRIGLYCERIDES liquicolor mono (HUMAN, Germany). Identification of cholesterol very low density lipoproteins (LDL-C) was performed by calculation according to the formula Friedwald: LDL-C = triglycerids / 2,18 . For reference interval accepted the concentration of LDL-C 0.18 - $0.82 \mathrm{mmol} / \mathrm{L}$. The quantitative determination of high density lipoprotein cholesterol (HDL-C) consists of two stages: the first stage - the removal from the reaction zone of chylomicrons, cholesterol very low density lipoprotein and low-density lipoprotein cholesterol by the action of enzymes (hollister esteraza, cholesterol oxidase, catalase, ascorbate); the second stage - definition of HDL-C widespread enzymatic method using a specific HDL-C surfactants (peroxidase, 4-aminophenazone). Measurement of the optical density was performed against the blank sample Reagent when $37^{\circ} \mathrm{S}$ and $546 \mathrm{~nm}$ on a biochemical analyzer («Labio 2000», China). Calculation of concentration is performed based on the content of cholesterol in the calibrator. For the lower reference interval accepted the concentration of HDL-C $0.9 \mathrm{mmol} / \mathrm{L}$. Identification of cholesterol low density lipoprotein (LDL) was carried out by calculation according to the formula Friedwald: LDL-C $=$ TC - (VLDL-C + HDL-C). For reference interval accepted the concentration of LDL-C of 0.3 - $3.80 \mathrm{mmol} / \mathrm{L}$. Atherogenic index was calculated the ratio of the amount of cholesterol atherogenic fractions to not atherogenic. The reference interval accepted from 2 to 4 . In the article used a quantitative description of the indicator of atherogenic fractions of cholesterol - LDL-C and atherogenic index.

Statistical analysis was performed using the statistical package «Statistica for Windows v. $6 \mathrm{Ru}$ » on a personal computer. For comparison of quantitative traits in two related samples was used Wilcoxon Matched Pairs Test. Results are presented as the median (Me) and interquartile span (25th and 75th percentiles). Forecasting was performed using multiple linear regression straight stepwise procedure of adding features. The critical level of significance of $p$ when checking all the above statistical hypothesis assumed to be equal 0.05 .

Work does not infringe the rights and does not endanger the well-being of employees surveyed in accordance with the requirements of biomedical ethics imposed Declaration of Helsinki of the World Medical Association (2000) and the Order of the Ministry of Health of the Russian Federation №266 (from 19.06.2003).

\section{RESULTS AND DISCUSSION}

The first clinical study of patients trained in contact with mercury hypertension in group I was registered at $18.75 \%$ of the patients, in the II group - $21.0 \%$ and III - in $34.6 \%$ of employees. Examination of the dynamics revealed a statistically significant increase in the frequency of occurrence of hypertension in all groups $(<0.05)$ (Table 1). Coronary heart disease in group 1 was not registered during the initial examination, and after 5 years, recorded 1 case of coronary heart disease; in Group II at the first examination was diagnosed in $5.2 \%$ of cases, and after 5 years showed a statistically significant increase of up to $10.5 \%(p=0.03)$; in group III coronary heart disease was observed in $7.6 \%$ of cases, and when re-examining the incidence rate increased almost 2 times and amounted to $15.4 \%(\mathrm{p}=0.03)($ Table 1$)$.

Determination of serum ceruloplasmin content showed a statistically significant increase in its content with the increase in work experience in all three groups. In the first group, with experience of 5-9 years, the age workers in contact with the mercury, was 33.0 (29-41) years, ceruloplasmin content originally was $27.0 \quad(24.2-29.0)$ 
$\mathrm{mg} / \mathrm{dL}$, when examining the dynamics - 39.2 (34.0- 43.2) $\mathrm{mg} / \mathrm{dL}(\mathrm{p}<0.05)$.

TABLE I. THE FREQUENCY OF FARDIOVASCULAR DISEASE IN GROUPS, $\%$ [CI]

\begin{tabular}{|l|c|c|c|c|c|c|}
\hline \multirow{4}{*}{ Indicators } & \multicolumn{4}{|c|}{ Groups } \\
\cline { 2 - 7 } & \multicolumn{2}{|c|}{$\begin{array}{c}\text { I (experience 5-9 } \\
\text { years) } \\
\mathbf{n = 3 2}\end{array}$} & \multicolumn{2}{c|}{$\begin{array}{c}\text { II experience 10- } \\
\text { 15 years), } \\
\text { n=19 }\end{array}$} & \multicolumn{2}{c|}{$\begin{array}{c}\text { III (experience } \\
\text { more than 15 } \\
\text { years), m = 26 }\end{array}$} \\
\cline { 2 - 7 } & $\begin{array}{c}\text { Examin } \\
\text { ation 1 }\end{array}$ & $\begin{array}{c}\text { Examin } \\
\text { ation 2 }\end{array}$ & $\begin{array}{c}\text { Examin } \\
\text { ation 1 }\end{array}$ & $\begin{array}{c}\text { Examin } \\
\text { ation 2 }\end{array}$ & $\begin{array}{c}\text { Examin } \\
\text { ation 1 }\end{array}$ & $\begin{array}{c}\text { Examin } \\
\text { ation 2 }\end{array}$ \\
\hline $\begin{array}{l}\text { Arterial } \\
\text { hypertensio } \\
\mathrm{n}\end{array}$ & 18.7 & $37.5^{*}$ & 21.0 & $47.3^{*}$ & 34.6 & $53.8^{*}$ \\
{$[12-22]$} & {$[33-45]$} & {$[17-28]$} & {$[29-45]$} & {$[29-39]$} & {$[41-55]$} \\
\hline $\begin{array}{l}\text { Coronary } \\
\text { artery } \\
\text { disease }\end{array}$ & - & 3.2 & $\begin{array}{c}5.2[2- \\
7]\end{array}$ & $\begin{array}{c}10.5^{*} \\
{[6-12]}\end{array}$ & $\begin{array}{c}7.6[4- \\
11]\end{array}$ & $\begin{array}{c}15.4 * \\
{[11-21]}\end{array}$ \\
\hline
\end{tabular}

* - comparison of the incidence of cardiovascular diseases in groups, $\chi 2$ Pearson / Yates correction at 1 and 2 examination, the differences were statistically significant $(\mathrm{p}<0,05)$.

In the second group experienced $10-15$ years (mean age group for the first stage of the survey - $38(35-49)$ years ceruloplasmin level in serum was equal to $24.9(21,0-29,0)$ $\mathrm{mg} / \mathrm{dl}$, and after 5 years of contact with mercury it had increased to $40.8(34.7-48.3) \mathrm{mg} / \mathrm{dl}(\mathrm{p}<0.05)$. In the third group with mercury experience more than 15 years, ceruloplasmin content increased from 25.7 (22.4-27.3) $\mathrm{mg} / \mathrm{dL}$ to $40.5(38.5-52.2) \mathrm{mg} / \mathrm{dl}(\mathrm{p}<0.05)$ (Table 2$)$.

The cholesterol content of LDL does not exceed the reference level in group 2 in both examination points, but in the first and third groups was a statistically significant increase in 5 years from the initial survey to $16.1 \%(-2.6$, 42.2) and $133 \%(8.5 ; 40.8)$, respectively. Noteworthy is the fact statistically significant increase in atherogenic index values in the dynamics of examination in all groups, most pronounced in the group of $1-44 \%(8.8 ; 66.7)$. At the same time, the highest values of this indicator reached in individuals with experience in hazardous conditions for more than 15 years.

The content of gamma-glutamyl transferase in groups does not exceed standard values, which excluded the presence of liver disease (Table 2).

Using multiple linear regression straight stepwise procedure of adding features got an equation that expresses the relationship of the variable (predicted concentration of ceruloplasmin) with indicators, considered as predictors: the concentration of gamma-glutamyl transferase in serum at the time of examination, ceruloplasmin concentration in the serum at the time of examination, calculated length of service in terms of mercury exposure to the predicted time at the time of the prediction ceruloplasmin concentration.

$$
\mathrm{Y}=-3.77665+0.31061 \times \mathrm{GGT} 1+0.00518 \times
$$

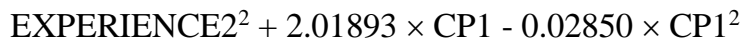
4-5 years;

$\mathrm{Y}$ - the predicted concentration of ceruloplasmin in

$$
\text { -3.77665 - Constant; }
$$

$0.31061, \quad 0.00518, \quad 2.01893,0.02850$ - predictor coefficients;

GGT1 - gamma-glutamyl transferase concentration in the serum at the time of examination (U/L), no greater than 200 $\mathrm{U} / \mathrm{L}$;

$\mathrm{CP} 1$ - ceruloplasmin concentration in the serum at the time of examination $(\mathrm{mg} / \mathrm{dL})$;

EXPERIENCE2 - experience of work in the conditions of mercury exposure over the forecast time (prediction) (seniority at the time of examination $+4-5$ years).

TABLE II. DESCRIPTIVE STATISTICS PARAMETERS STUDIED

\begin{tabular}{|c|c|c|c|c|c|c|}
\hline \multirow{3}{*}{ Indicators } & \multicolumn{6}{|c|}{ Groups } \\
\hline & \multicolumn{2}{|c|}{$\begin{array}{c}I \text { (experience } 5-9 \\
\text { years) } \\
n=32\end{array}$} & \multicolumn{2}{|c|}{$\begin{array}{c}\text { II (experience 10- } \\
15 \text { years), } \\
n=19\end{array}$} & \multicolumn{2}{|c|}{$\begin{array}{c}\text { III (experience } \\
\text { more than } 15 \\
\text { years), } m=26\end{array}$} \\
\hline & $\begin{array}{c}\text { Exami } \\
\text { nation } \\
1\end{array}$ & $\begin{array}{c}\text { Exami } \\
\text { nation } \\
2\end{array}$ & $\begin{array}{c}\text { Exami } \\
\text { nation } \\
1\end{array}$ & $\begin{array}{c}\text { Exami } \\
\text { nation } \\
2 \\
\end{array}$ & $\begin{array}{c}\text { Exami } \\
\text { nation } \\
1\end{array}$ & $\begin{array}{l}\text { Exami } \\
\text { nation } \\
\quad 2 \\
\end{array}$ \\
\hline $\begin{array}{l}\text { Age at the time } \\
\text { of the } \\
\text { examination, } \\
\text { years }\end{array}$ & $\begin{array}{l}33 \\
(29- \\
41)\end{array}$ & $\begin{array}{l}37 \\
(33- \\
45)\end{array}$ & $\begin{array}{c}38 \\
(35- \\
49)\end{array}$ & $\begin{array}{l}42 \\
(39- \\
53)\end{array}$ & $\begin{array}{l}45 \\
(42- \\
51)\end{array}$ & $\begin{array}{c}49 \\
(46- \\
55)\end{array}$ \\
\hline $\begin{array}{l}\text { Work } \\
\text { experience in } \\
\text { contact with } \\
\text { the mercury at } \\
\text { the time of } \\
\text { examination, } \\
\text { years }\end{array}$ & $\begin{array}{l}7.0 \\
(6.0- \\
7.0)\end{array}$ & $\begin{array}{c}11.0 \\
(10.0- \\
11.0)\end{array}$ & $\begin{array}{l}11.5 \\
(10- \\
13)\end{array}$ & $\begin{array}{l}15.5 \\
(14- \\
17)\end{array}$ & $\begin{array}{l}20.5 \\
(17- \\
23)\end{array}$ & $\begin{array}{l}24.5 \\
(21- \\
27)\end{array}$ \\
\hline $\begin{array}{l}\text { The content of } \\
\text { ceruloplasmin, } \\
\mathrm{mg} / \mathrm{dL}\end{array}$ & $\begin{array}{l}27.0 \\
(24.2- \\
29.0) \\
\end{array}$ & $\begin{array}{c}39.2 \\
(34.0- \\
43.2) \\
\end{array}$ & $\begin{array}{c}24.9 \\
(21,0- \\
29,0) \\
\end{array}$ & $\begin{array}{c}40.8 \\
(34.7- \\
48.3) \\
\end{array}$ & $\begin{array}{c}25.7 \\
(22.4- \\
27.3) \\
\end{array}$ & $\begin{array}{c}40.5 \\
(38.5- \\
52.2) \\
\end{array}$ \\
\hline $\begin{array}{l}\text { p Wilcoxon } \\
\text { Test }\end{array}$ & \multicolumn{2}{|c|}{0,000008} & \multicolumn{2}{|c|}{0,04} & \multicolumn{2}{|c|}{0,002} \\
\hline $\begin{array}{l}\text { Contents GGT, } \\
\mathrm{U} / \mathrm{L}\end{array}$ & $\begin{array}{c}27.3 \\
(20.0- \\
45.3) \\
\end{array}$ & $\begin{array}{c}28.0 \\
(22.0- \\
44.0) \\
\end{array}$ & $\begin{array}{c}32.1 \\
(24.2- \\
56.1) \\
\end{array}$ & $\begin{array}{c}30.0 \\
(21.0- \\
53.0) \\
\end{array}$ & $\begin{array}{c}31.9 \\
(25.4- \\
39.9) \\
\end{array}$ & $\begin{array}{c}28.0 \\
(23.0- \\
52.0) \\
\end{array}$ \\
\hline $\begin{array}{l}\text { p Wilcoxon } \\
\text { Test }\end{array}$ & \multicolumn{2}{|c|}{0,9} & \multicolumn{2}{|c|}{0,2} & \multicolumn{2}{|c|}{0,7} \\
\hline $\begin{array}{l}\text { LDL } \\
\text { Cholesterol, } \\
\mathrm{mmol} / \mathrm{L}\end{array}$ & $\begin{array}{l}3.21 \\
(2.5- \\
3.5) \\
\end{array}$ & $\begin{array}{c}3.52 \\
(2.96- \\
3.8)\end{array}$ & $\begin{array}{c}3.32 \\
(2.23- \\
3.72) \\
\end{array}$ & $\begin{array}{c}3.35 \\
(2.94- \\
4.25) \\
\end{array}$ & $\begin{array}{l}3.35 \\
(2.75- \\
4.04) \\
\end{array}$ & $\begin{array}{c}4.02 \\
(3.45- \\
4.80) \\
\end{array}$ \\
\hline $\begin{array}{l}\text { p Wilcoxon } \\
\text { Test }\end{array}$ & \multicolumn{2}{|c|}{0,004} & \multicolumn{2}{|c|}{0,9} & \multicolumn{2}{|c|}{0,0009} \\
\hline $\begin{array}{l}\text { Atherogenic } \\
\text { index (AI) }\end{array}$ & $\begin{array}{c}3.1 \\
(2.4- \\
3.6) \\
\end{array}$ & $\begin{array}{c}4.2 \\
(3.2- \\
5.0) \\
\end{array}$ & $\begin{array}{c}4.2 \\
(2.6- \\
4.8) \\
\end{array}$ & $\begin{array}{c}4.9 \\
(3.9- \\
5.4) \\
\end{array}$ & $\begin{array}{c}4.1 \\
(3.0- \\
4.7) \\
\end{array}$ & $\begin{array}{c}5.2 \\
(3.7- \\
6.7) \\
\end{array}$ \\
\hline $\begin{array}{l}\text { p Wilcoxon } \\
\text { Test }\end{array}$ & \multicolumn{2}{|c|}{0,001} & \multicolumn{2}{|c|}{0,1} & \multicolumn{2}{|c|}{0,001} \\
\hline
\end{tabular}
GROUPS, ME (Q25-Q75)

Forecasting the development of cardiovascular disease in workers exposed to mercury is carried out as follows. The patient has fasted blood sampling from the cubital vein using vacuum systems with a blood clotting activator (for serum). Determine the level of ceruloplasmin and activity of gammaglutamyl transferase in serum, calculate the experience of work in terms of mercury exposure in 4-5 years from now. The results of the patient examination is substituted into the equation obtained by the method of multiple linear regression straight stepwise procedure of adding features. 
Example 1. Patient A. (male, 23 years) work experience in contact with the metal mercury vapor 4 years. At the time of examination CP blood serum - $29.7 \mathrm{mg} / \mathrm{dl}$, GGT - 18.6 U/l. Atherogenic index at the time of examination - 2.17, LDL-C- $1.58 \mathrm{mmol} / \mathrm{L}$.

Expect the projected content of $\mathrm{CP}$ in 4 years:

$$
\mathrm{Y}=-3.77665+0.31061 \times 8.6+0.00518 \times 8^{2}+
$$
$2.01893 \times 29.7-0.02850 \times(29.7)^{2}=36.6 \mathrm{mg} / \mathrm{dl}$.

The measured concentration of serum ceruloplasmin in 4 years was $38.7 \mathrm{mg} / \mathrm{dl}$. Deviation from the projected level of ceruloplasmin was actually $5 \%$.

Conclusion: Given that the lipid metabolism at the time of examination at the bottom border of the reference, the projected increase in the level of ceruloplasmin in 4 years will not contribute to the formation of atherosclerosis and dyslipidemia. The actual value of IA and LDL-C in 4 years amounted to 2.73 and 2.84 , respectively, it is unlikely the development of oxidation pro-atherogenic lipoprotein fractions and the development of the pathological process.

Example 2. Patient E. (male, 52), mechanic, work experience in contact with the metal mercury vapor 13 years. At the time of examination CP blood serum - $21.1 \mathrm{mg} / \mathrm{dl}$, GGT - $45.8 \mathrm{U} / \mathrm{l}$. Atherogenic index at the time of examination - 5.36, LDL-C - $2.71 \mathrm{mmol} / \mathrm{L}$.

Expect the projected content of CP in 4 years:

$$
\mathrm{Y}=-3.77665+0.31061 \times 45.8+0.00518 \times 172+
$$
$2.01893 \times 21.1-0.02850 \times(21.1) 2=38.8 \mathrm{mg} / \mathrm{dl}$.

Measured concentration in serum ceruloplasmin 4 years was $40.5 \mathrm{mg} / \mathrm{dl}$. Deviation from the projected level of ceruloplasmin was actually $4.3 \%$.

Conclusion: Considering that the atherogenic index at the time of examination is above the reference limits projected increase in the level of ceruloplasmin in 4 years will exacerbate developing disorders that requires treatment and preventive measures, aimed not only at correcting lipid metabolism, but also to the patronage of lipids by oxidative oxidation. The actual value of IA and LDL-C after 4 years amounted to 4.92 and 3.28, respectively.

With increasing content of ceruloplasmin and developing pro-atherogenic violations of the risk of cardiovascular disease increased.

Example 3. Patient T. (male, 49 years), the mechanic, the work experience in contact with metallic mercury vapors for 21 years. At the time of examination CP blood serum - 29.8 $\mathrm{mg} / \mathrm{dl}$, GGT - 53.7 U/l. Atherogenic index at the time of examination - 2.72, LDL-C - $3.3 \mathrm{mmol} / \mathrm{l}$.

Expect the projected content of CP in 5 years:

$$
\mathrm{Y}=-3.77665+0.31061 \times 53.7+0.00518 \times 262+
$$

$2.01893 \times 29.8-0.02850 \times(29.8) 2=46.9 \mathrm{mg} / \mathrm{dl}$.
Measured concentration in serum ceruloplasmin at 5 years was $47.0 \mathrm{mg} / \mathrm{dl}$. Deviation of the projected level of ceruloplasmin on the actual was $0.2 \%$.

Conclusion: The analysis of biochemical parameters at the time of examination allows us to conclude that the atherogenic index - normal, LDL-C also does not go beyond the boundaries of acceptable values, but close to the upper border of the reference $(3.8 \mathrm{mmol} / \mathrm{l})$. Considering the significant increase in the predicted concentration of ceruloplasmin in 4 years (57\%), should expect an intensification of pro-atherogenic process, requiring preventive measures, aimed primarily at enhancing antioxidant protection. The actual value of IA and LDL cholesterol after 4 years amounted to 5.59 and 4.3 respectively. Against the background of a significant increase in ceruloplasmin content and form of dyslipidemia risk of developing cardiovascular disease increased.

The development of oxidative stress plays an important role in the pathogenesis of cardiovascular diseases. As a result, the activation of vasoconstriction, increased platelet aggregation, adhesion of neutrophils to the endothelium, migration of granulocytes and monocytes. In recent years, new data were obtained on the significance of ceruloplasmin in the development of oxidative stress and its role in maintaining oxidative balance. This protein belongs to the copper-containing glycoprotein $\alpha 2$-globulin fraction of serum, synthesized primarily in the liver parenchymal cells as well as in lymphocytes, monocytes, spleen, brain and other tissues [15]. The CP performs a number of important body for vital body functions: control of copper metabolism necessary for normal metabolic processes in the hematopoietic and immune systems, brain, myocardium; superoxide dismutase synthesis - active endogenous antioxidant; carries ferroxidase action and immobilization of serum iron; antioxidant activity; participate in acute-phase response; regulation levels of biogenic amines in the body $[16,17]$. CP is a natural regulator of oxidative, having proand antioxidase activity. Oxidative activity of this protein is related to the presence of copper in its composition. When removing the copper atoms of the molecule $\mathrm{CP}$ lost its oxidant properties. As prooxidant $\mathrm{CP}$ enhances oxidation of ascorbic acid, catecholamines, serotonin, and compounds containing sulfhydryl groups, such as cysteine and homocysteine. Role of CP proved in the oxidation of LDL, which is one of the most important processes in the development of atherogenesis [18]. In this connection, the results were obtained on the role of $\mathrm{CP}$ in the regulation of angiogenesis, atherosclerosis, coronary heart disease, congestive heart failure $[19,20]$. Recent studies also support a role in the regulation of homeostasis CP nitric oxide [21], which is a reduction of the pathogenetic links of both atherosclerosis and endothelial dysfunction.

Dynamic examination of trained workers in contact with the mercury, showed a clear increase in hypertension and coronary heart disease with increasing work experience. The incidence of hypertension and coronary heart disease increased by $1.5-2$ times, exceeding the general population prevalence rates in these age groups [22]. Analysis of biochemical parameters at the time of examination allows 
stating that the atherogenic index increases with increasing exposure mercury load, LDL-C does not go beyond the boundaries of acceptable values, but close to the upper border of the reference $(3.8 \mathrm{mmol} / \mathrm{l})$. Considering the significant increase in the predicted concentration of ceruloplasmin in 4-5 years, should be expected an intensification of pro-atherogenic process, requiring preventive measures, aimed primarily at enhancing antioxidant protection.

Application of the method of mathematical forecasting of changes in the level of biochemical parameters, in particular, ceruloplasmin, which plays a pathogenic role in the development of CVD, allows, on the one hand, timely detect these changes, and, on the other hand, in a timely manner to carry out preventive and curative measures aimed at preserving the health of the working population.

\section{CONCLUSION}

In workers exposed to mercury, the risk of developing cardiovascular disease increases against the backdrop of a significant increase in ceruloplasmin content and form of dyslipidemia. Consequently, for periodic medical examinations should be determined in the serum levels of ceruloplasmin and to forecast changes in its concentration. Based on forecasted build-up level of the protein in the serum of trained workers in contact with the mercury, it is necessary to apply a set of preventive and therapeutic measures aimed at activation of antioxidant protection, with subsequent transfer of a worker is exposure to toxic substances.

\section{REFERENCES}

[1] J.T. Salonen, K. Seppänen, T.A. Lakka, « Mercury accumulation and accelerated progression of carotid atherosclerosis: a population-based prospective 4-year follow-up study in men in eastern Finland», Atherosclerosis, vol. 1482000, № 2, pp. 265-273.

[2] B.O. Lund, D.M. Miller, J.S. Woods, «Studies on Hg(II)induced $\mathrm{H} 2 \mathrm{O} 2$ formation and oxidative stress in vivo and in vitro in rat kidney mitochondria", Biochem. Pharmacol., vol. 45, № 101993, pp. 2017-2024.

[3] J.C. Klein, C.G. Crandall, R.M. Brothers, «Combined heat and mental stress alters neurovascular control in humans», J. Appl. Physiol., vol. 109, № 62010, pp. 1880-1806.

[4] T. Rissanen, S. Voutilainen, K. Nyssönen «Fish oilderived fatty acids, docosahexaenoic acid and docosapentaenoic acid, and the risk of acute coronary events: the Kuopio ischaemic heart disease risk factor study», Circulation, vol. 102, № 22, 2000, pp. 26772679.

[5] J.K. Virtanen, S. Voutilainen, T.H. Rissanen «Mercury, fish oils, and risk of acute coronary events and cardiovascular disease, coronary heart disease, and allcause mortality in men in Eastern Finland», Arteriosclerosis, Thrombosis and Vascular Biology, vol. 25, № 1, 2005, pp. 228-233.
[6] K. Yoshizawa, E.B. Rimm, J.S. Morris « Mercury and the risk of coronary heart disease in men», The New England Journal of Medicine, vol. 347, № 222002, pp. 1755-1760.

[7] E.V. Katamanova «Violations of the functional activity of the brain during occupational exposure neurotoxicants»: Abstract. Dis ... Dr. med. Sciences. Irkutsk, 2012, 47 p.

[8] I.V. Kudaeva «The role of oxidative stress in the pathogenesis of occupational diseases arising from exposure to toxic substances»,, J. of New Medical Technologies, № 1, 2009, p. 253.

[9] I.V. Kudaeva, L.A. Budarina «Dynamic study of lipid metabolism in workers exposed to mercury», Fundamental research, № 5, 2012, pp. 52-57.

[10]I.V. Kudaeva, L.A. Budarina «The change of biochemical parameters when exposed to vapors of metallic mercury», Bulletin of the East Siberian Scientific Center of the Academy of Medical Sciences, № 6 (88), 2012, pp. 24-27.

[11] M. Manttari, V. Manninen, J.K. Huttunen, «Serum ferritin and ceruloplasmin as coronary risk factors», Eur Heart J., № 15, 1994, pp. 1599 - 1603.

[12] E. Ehrenwald, G.M. Chisolm, P.L. Fox, «Intact human ceruloplasmin oxidatively modifies low density lipoprotein», J. Clin. Invest., №93(4), 1994, pp. 14931501 .

[13] A.Y. Göçmen, E. Sahin, E. Semiz, S. Gümuşlü, «Is elevated serum ceruloplasmin level associated with increased risk of coronary artery disease?», Can. J. Cardiol., № 24, 2008, pp. 209-212.

[14] P.L. Fox, B. Mazumder, E. Ehernwal, «Ceruplasmin and cardiovascular disease», Free Radical Biology \& Medicine, № 28(12), 2000, pp. 1735-1744.

[15] V.I. Vashchenko, T.N. Vashchenko, «Ceruloplasmin from metabolite to drug», Psychopharmacology and Biological Narcology, vol. 6 (3), 2006, pp. 1254-1269.

[16] K.A. Moshkov, V.N. Zaitsev, E.V. Fomanovskaya, V.E. Stefanov, «Ceruloplasmin: intramolecular electron transfer and ferroksidaznaya activity», Fundamental research, №3, 2014, pp. 104-108.

[17] R.L. Poltava, G.N. Chupahina, T.V. Meleshenko, «The antioxidant system of the blood of patients with alcohol dependence», IKBFU's Vestnik, №7, 2012, pp. 28-32.

[18] Razvan T. Dadu, Rhiannon Dodge, Vijay Nambi «Ceruloplasmin and heart failure in the atherosclerosis risk in communities (ARIC) study», Circ. Heart Fail., № 6(5), 2013, pp. 936-943.

[19] W.H. Tang, Y. Wu, J. Hartiala « Clinical and genetic association of serum ceruloplasmin with cardiovascular risk», Arterioscler Thromb Vasc. Biol., №32, 2012, pp. 516-522.

[20] H.J. Kim, H.S. Yoo, P.K. Kim «Comparative analysis of serum proteomes of patients with cardiovascular disease», Clin. Biochem., № 44, 2011, pp. 178-184.

[21] S. Shiva, X. Wang, L.A. Ringwood, «Ceruloplasmin is a NO oxidase and nitrite synthase that determines endocrine NO homeostasis»», Nat. Chem. Biol., № 2, 2006, pp. 486-493.

[22] O.M. Drapkina, «Coronary artery disease: The main directions of therapeutic intervention», Consilium Medicum, vol. 3 (1), 2005, p. 8. 
